\title{
Democratization System about Anti-corruption and Uphold Integrity
}

\author{
Peiyong Hou \\ Northwestern polytechnical University, Xi'an 710072, China \\ E-mail: hpynwpu@sohu.com
}

\begin{abstract}
This article outlines the inevitability of democratization system of anti-corruption and uphold integrity, and analyzes the current situation and causes concerned, thereby introducing the idea of democratization system of anti-corruption and uphold integrity. It Points on relevant solutions of anti-corruption and uphold integrity, intensifying public democracy education and improvement democratization system in anti-corruption and uphold integrity, at the same time, it more try to find out the way of thinking for democratization system of anti-corruption and uphold integrity in China. The democratic consciousnesses are thinking basic of anti-corruption and uphold integrity. The democratic systems are poise of restricting power of anti-corruption and uphold integrity. The democratic enlist is strength headspring of anti-corruption and uphold integrity.
\end{abstract}

Keywords: Anti-corruption, Uphold integrity, System analysis, Democratization

\section{Introduction}

Anti-corruption and uphold integrity, has become a common concern about serious political issues in different countries. This study is universal topic of anti-corruption and upholds integrity. There is different state of the nation in the different nation. It is worthy of considering how anti-corruption and uphold integrity in China. What is the anti-corruption and upholds integrity relied on? It is must depends on the system. The system is officiating by personnel. It is enslaved to social democratization for personnel officiating system.

No stipulation's power is springhead of induce corruption. In many localities or departments, some official reception clearly beyond the reasonable power areas, that becomes important manifestations of corruption. The norms and reform of official power is imperative. Some government organs exertion power currently, such as ultra-category, jobbery and other issues. This is to say, official powers regulate, are a major event in promoting the reform of the administrative system, combat corruption and improve the bureaucracy. on the basis of full analysis these issues and harm caused, according to our government administration actual situation and learning from the experience of some foreign countries, a number specific proposals of regulating government power of the are bring forward, such as the reasonable definition of official power, the rigidity of the power constraint, the operational system, the strength of technical anti-corruption and uphold integrity, and the allocation of resources standardize, the operation of power monitored, the supervision strengthened and the public service improved.

\section{Methodological choice in progress}

It has spent a lot of effort that should be placed on upholding integrity, supervision of power and clean and honest governance with the anti-corruption and upholds integrity work over the past years. The state has intensified correction of unhealthy social practices and exerted great efforts to resolve problems that harm the interests of the public, greatly promoted governance according to law and seriously dealt with irregularities and commercial bribery so as to root out corruption. It has been serious penalties toward corruption, especially those involving government officials. The collusion between officials and business, trade between power and money, power and sex, and cases seriously infringing upon public interest should receive heavy punishment. The commercial bribery cases involving civil servants and leaders of state enterprises, public and financial institutions accepting and sending bribes by abusing power would be seriously handled in line with the law. A lot of effective measures have been adopted to strike commercial bribery activities on the Chinese mainland organized by overseas economic organizations. These have be launched to deal with overseas sightseeing tours funded by public money and construction of luxurious buildings in special government 
campaigns. China has strengthened its anti-corruption work under the framework of the United Nations Convention Anti-Corruption in recent years. The state had also stepped up its international cooperation to recover money taken abroad by runaway government officials involved with major economic crimes. These have demonstrated the resolution of the Communist Party of China Central Committee to build a clean party, promote clean governance and fight corruption. "Whoever it is, no matter how high their positions are, anyone who violates party rules or national law will be severely punished".

However, for long time, the superincumbent path was relied on anti-corruption principally. It is only call for leaders of various departments to strictly comply with self-discipline rules and uphold integrity. Although the strength of this instrumentality work up to increase for sure, public could not obtain to be concerned with anti-corruption and uphold integrity from top to bottom and fret one's gizzard little by little. This may be a special difficulty in Chinese state.

There is many method of anti-corruption and upholds integrity in the world. Advantage and weakness is existent in the each method. For example, severe punishment ran a country could keep the corrupted phenomenon within limits in initial stage effectively on one hand, but produced non-democracy in the administration and local officials passively on the other hand. The limited consensus may increase the difficulty of attacking corruption in practices. We should come out the mistake area of the severe punishment ran a country, to avoid blindness on the penalty, and to run into no realistic severe punishment mistake. For instance, Hong Kong Independent Commission against Corruption (ICAC) is a kind of advanced mode. This kind of mode depend the independent mechanism with the society's democracy.

In reality, the democratization system of anti-corruption and uphold integrity is all along assertion of communist people. Mr. Yen-pie Huang thought the corruption is provided with periodic law in an act of god. While he visited Zedong Mao in Yen' an, he had had consultation for Zedong Mao how does the communist avoid this periodic law about corruption? Zedong Mao replied to him by the word of democracy.

Recently, Jintao Hu, general secretary of the Communist Party of China (CPC), presided over a meeting of the Political Bureau of the CPC Central Committee ahead of the party's 88th birthday. He has called for more to attach importance to push democracy development inside party on our own initiative. (People's Daily, 2009, 7, 1) He said the Party will establish a sound system under which the Political Bureau of the Central Committee regularly reports its work to plenary sessions of the Central Committee and accepts their oversight, and the standing committees of local Party committees at all levels do likewise to plenary sessions of local Party committees and accept their oversight. At the same time, the article of the democracy to weave anti-corruption tight encirclement is published in People Newspaper on August 31,2009. The article direct point is the power more concentrate and the democracy more difficult expressly. The article appeal to guarantee know the inside story right and superintendence of common party member and to accelerate the democracy, setting a limit the power, anti the corruption in Chinese state currently. (People's Daily, 2009, $8,31)$ This voice doubtless reveal out some considers with the trend that high layer search after anti-corruption and uphold integrity and investigate political civilization developments in People's Daily, as a result it is particularly attention-getting. It will indicate that anti-corruption and uphold integrity more turned up to the Chinese characters democracy. Such purpose is for the sake of enhancing the Communist Party's ruling capacity and leadership in the national development. We must pay greater attention to inner-party democracy actively. As these will help we perform our duty with a ruling party by more scientific and democratic accordance ways, we must promote inner-party democracy and social democracy.

The democratization system of anti-corruption and uphold integrity is choice in developmental course. The democratization system of anti-corruption and uphold integrity is inevitable in history development of anti-corruption and uphold integrity. The democracy is a basic method of restricting power. It is an ultimate means to ravel out corruption. The democratic consciousnesses are thinking basic of anti-corruption and uphold integrity. The democratic systems are poise of restricting power of anti-corruption and uphold integrity. The democratic enlist is strength headspring of anti-corruption and uphold integrity. It couldn't bring into play fully for democratization supervised at the present time. Concretely, it is short of the system, there isn't a suit of whole system, ensuring run of democratization supervised. Many are devoid of polity fervor, consciousness of democratization right and activity atmosphere. These result in great and concentrate power excessively. Therefore, as an important part of China's overall reform, political restructuring must be constantly deepened along with economic and social development to adapt to the growing enthusiasm of the people for participation in political affairs. We need to intensify investigation and research. Anti-corruption and uphold integrity must be flexible enough to cope with new situations and solve new problems.

\section{How to practice the democratization system?}

Good system could make malefactor unable to run amuck, not good system could make a good sort unable to work sufficiency. The democratization is one of the most extensively used political concepts. How to practice the democratization system of anti-corruption and uphold integrity? On condition that democratization system of anti-corruption and uphold integrity put into practice in word and deed, democracy with freedom and equality would be must be absolutely necessarily. The democracy, freedom and equality are three key influential factors of anti-corruption 
and uphold integrity. Focusing on special issues of the democratization system of anti-corruption and uphold integrity, the Figure below described their mutual functions of the democracy, freedom and equality. The democracy, freedom and equality are depended upon subsisting indispensability interdependently. First key influential factor is freedom. The freedom could ensure to come into being strength of anti-corruption and uphold integrity. The individual or groups are independence status of anti-corruption and uphold integrity. For instance, the free press and public opinion is free. Second key influential factor is equality. The citizen possesses the equal rights. For instance, the supervisor and accepter are in possession of the equal rights. Third key influential factor is democracy. The democracy oversight must be provided higher authority. The basic effective and extensive way for the people to be masters of the country is that people directly exercise democratic rights in accordance with the law to manage public affairs and public service programs at the primary level, practice self-management, self-service, self-education and self-oversight, and exercise democratic oversight over cadres. If official business power to realizes, it is must pay attention to right process and strengthen legal system. For example, the development of inner-party democracy must depend on the guarantee of democratic rights to know, to participate, to vote and to supervise for all Party members in all internal affairs of the Party. All Party members should be encouraged to supervise and suggest on all matters concerning inner-party democracy, such as the work to fight corruption inside the Party. The mechanisms to ensure the inner-party democracy must be improved, such as the congresses at some levels, and the system to elect, supervise, evaluate and promote officials. We need gradually extend direct election of leading members in primary Party organizations, and explore various ways to expand inner-Party democracy at the primary level. We must be to expand inner-Party democracy to develop people's democracy by increasing transparency in Party affairs and preventing arbitrary decision-making by an individual or a minority of people.

\section{Insert Figure 1 Here}

If the social democracy is put into practice far and wide, it is the most important to be provided with integrity. Integrity is the quality of being honest and of always having high moral principles. It is nothing doing to lose the integrity for an individual to an organization. There are personal integrity, public integrity, organizational integrity, government integrity and national integrity.

In order to ensure scientific and democratic decision-making, it improving the information and intellectual support for it, increasing its transparency and expanding public participation in it. Public hearings must be held for the formulation of laws, regulations and policies that bear closely on the interests of the public. All of individual and organization could join to remove its root cause, take preventive measures, and improve relevant systems forwardly.

It is needed innovate with new machine-made rules to promote Governmental entities transparency, in order to strengthen the corruption fight and promoting a clean government. These are the importance of a scientific and democratic decision-making process. Policies regarding the immediate interest of the masses should be made by soliciting public opinions or holding hearings so as to enhance public participation and receive public supervision. Public official should demonstrate achievement and personal integrity, and should increase their own ethical and cultural progress. We must reform power restricting system of officials on the basis of science and transparency. These will be expand people's democracy and ensure that people are masters of the country really and truly. The party members of the Communist Party of China have been nearly 76 million out of the 1.3 billion Chinese populations. Therefore it is hold the balance effect to anti-corruption and uphold integrity. We must expand inner-Party democracy to develop people's democracy. We ought to improve institutions of democracy, diversify its forms and expand its channels, and put into effect democratic election, decision-making and administration and oversight in accordance with the law to guarantee the people's rights to be informed, to participate, to be heard and to oversee. The Party need reform the inner-Party electoral system and improve the system for nominating candidates and electoral methods. The Party organizations must strictly implement democratic centralism; improve the system that combines collective leadership with division of responsibilities among individuals. It is sticking point that Party committees will adopt a voting system in discussing and deciding on major issues and appointing cadres to important positions. Party organizations at all levels and all Party members ought to take the lead in upholding the authority of the Constitution and the law. It needs to improve the mechanism of restraint and supervision. Power must be exercised in the sunshine to ensure that it is exercised correctly. The organic laws and rules of procedure should be improved to ensure that state organs exercise their powers and perform their functions within their statutory jurisdiction and in accordance with legal procedures.

\section{Conclusion}

All in all, it is a systems engineering for anti-corruption and uphold integrity, dealing with social very field, to require whole set measure. The democracy development is basic precondition of anti-corruption and upholds integrity. The inner-Party prevention and punishment of corruption is primary. The democracy development is an important footstone of Socialism modernizes. This is the basic direction that modern public power runs. It is seasoned with Socialism market economy. It is basic ensure of anti-corruption and uphold integrity to workout narrow system net with technical means. 
The democracy development is a long-terms gradually unused process. It need be supervised from grass roots party member, from societal public, and demand a system channel to concentrate sporadic opinions. We need make an aims at establishing a democracy system to punish and prevent corruption for long-term. The anti-corruption aims should take into account the prevention of corruption along with punitive measures, which would combine punishment with education, supervision of officials and improving China's judicial system. We must fully inspire the creativity and vigor of societal public, we must be converge public wisdom and strength to an utmost level, in order to advance social democracy development of China. The democracy supervise consciousness need improve with educate means. Awaking many, arming many and starting many, building up ideas of People benefits higher than everything and country benefits higher than everything. We need accelerate the separation of the functions of the government from those of enterprises, state assets management authorities, public institutions and market-based intermediaries, standardize administrative practices, strengthen administrative law-enforcement agencies, reduce the number of matters requiring administrative examination and approval and standardize such procedures, and reduce government intervention in microeconomic operations. The governance transparency should be further improved to safeguard the public rights to knowledge, participation, expression and supervision. The power must be restrict and supervised by public. Such as, the work order is publicity, the work result is publicity. The obscurer work is an importance approach of running power for individual. Only supervisory function enough can prevent to lose control power, to misplay decision-making and disqualification behavior. The democracy development is a long-terms gradually unused process. No other than these, societal public can become aware of own power, the societal basic of anti-corruption and uphold integrity could be strike up.

Currently, the request of anti-corruption and uphold integrity is higher and higher, the task is heavier and heavier, the difficulty is greater and greater. We need hold on created to intensify corruption fighting and conduct additional international exchanges in the field. Studying and implementing scientific outlook on development, adapting new position, we must pay attention to construct democratization system. Making passiveness treatments to initiative keep away, changing keeping within limits corruption to preventing corruption, we try hard to enhance anti-corruption legal system level, gradually consummate education of anti-corruption and uphold integrity extended mechanism, system and power supervised. Above these, there are certain reference meanings to today's work of anti-corruption and uphold integrity and building a clean and honest society.

\section{References}

Gao, Lan \& Li, Juan. (2008). Strengthening the Consciousness of Inner-Party Democracy is the Basis to Operate the Inner-Party Democracy. Tribune of Study, 24(2).

Hu, Jintao. (2009). To attach importance to push democracy development inside party. People's Daily, 7, 1

Huang, Shaoping \& Jiang, Zheng. (2007). Anti-Corruption System and System for Fighting against Corruption. Journal of Zhenzhou Communist Party College, 2.

Jin, Anping. (2009). Inner-party Democracy and Democratization of Party Thought on the Mechanism of Inner-party Driving People's Democracy. Social Science Research, 1.

Ling, Qi \& Hou, Yukan. (2007). A study on the Quality systems-Modal for Quality Management of Manufacturing. Modern Applied Science, 3(1).

Liu, Songshan. (2005). Two Tier Constructions of Democracy in the Party and People. Political Science and Law, 5.

Pan, Ruiji. (2009). The power more concentrate and the democracy more difficult. People's Daily, 8, 31.

Peng, Jingyi. (2007). Three Changes in the Endeavor to Fight Corruption and Uphold Integrity. Theory Battlefront, 23.

Sheng, Jiagen. (2006). Pondering upon Democracy inside the Party with Multiple Dimensions. Hubei Social Sciences, 11.

Xu, Furong. (2008). Construction of Anti-corruption by Institution in the Perspective of Rule of Law. Journal of Chengdu Aviation technology College, 24(3).

Zhang, Koulin. (2005). On Breaking and Building of our Party's Internal Democracy Development. Theory Monthly, 11. Zhou, Shenglong. (2008). Inner-party Democracy: The Motivation of Chinese Democratic Political Development. Journal of Hengshui University, 10(6). 


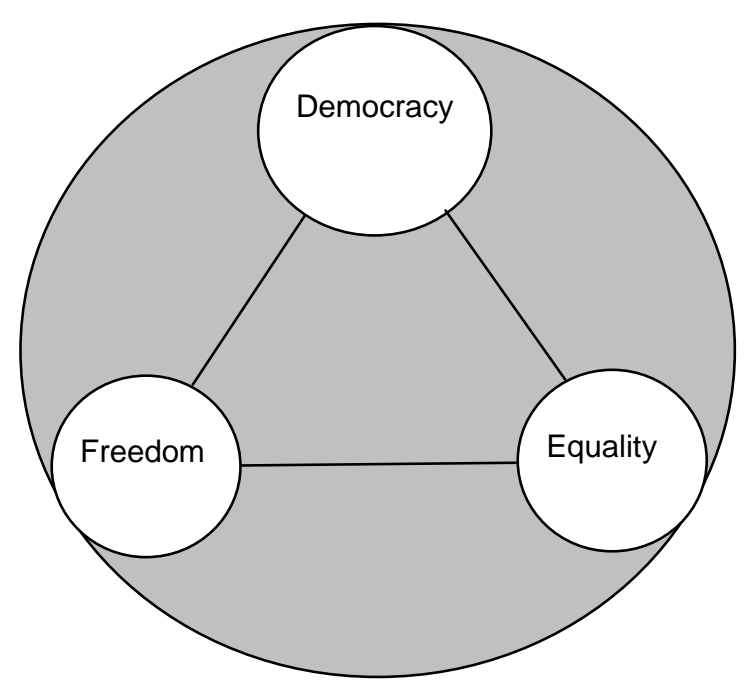

Figure 1. The three momentum model of democratization system of anti-corruption 